\title{
ON THE GENUS EXOPALAEMON (DECAPODA, CARIDEA, PALAEMONIDAE) IN GUANGDONG PROVINCE, SOUTHERN CHINA
}

\author{
BY
}

\author{
ZHAO LIANG GUO ${ }^{1,3}$ ), XIAO QING WANG ${ }^{2,4}$ ) and JI PING ZHANG ${ }^{1,5}$ ) \\ ${ }^{1}$ ) Department of Animal Science, Foshan Science and Technology College, Nanhai, 528231 \\ Guangdong Province, People's Republic of China \\ 2 ) Department of Fisheries, Hunan Agriculture University, Changsha, 410128 Hunan Province, \\ People's Republic of China
}

\begin{abstract}
Four species of white prawns of the genus Exopalaemon are recorded from Guangdong Province, southern China, including one new species, Exopalaemon guangdongensis, and a new record, E. modestus (Heller, 1862). E. guangdongensis new species is distinguished from its closely similar congeners by its rostral formula, the form of the four posterior abdominal somites, the ratios of the segments of the second pereiopod, and the size of its eggs. A key to the known Exopalaemon species from China is provided.
\end{abstract}

\section{RÉSUMÉ}

Quatre espèces de crevettes blanches du genre Exopalaemon sont rapportées de la province de Guangdong, au sud de la Chine, incluant une espèce nouvelle, Exopalaemon guangdongensis, et un nouveau signalement, E. modestus (Heller, 1862). La nouvelle espèce, E. guangdongensis, se distingue de ses plus proches congénères par sa formule rostrale, la forme des quatre somites abdominaux postérieurs, les rapports des segments du second péréiopode, et la taille de ses œufs. Une clé des espèces connues d'Exopalaemon de Chine est donnée.

\section{INTRODUCTION}

Holthuis (1950) created Exopalaemon as a subgenus of Palaemon based on Palaemon styliferus $\mathrm{H}$. Milne Edwards, 1840 as the type species, and recognized seven species in it. He (Holthuis, 1980) subsequently promoted Exopalaemon

\footnotetext{
3) Contact address: Room 504, No. 30, Pingyuanheng Street, Fenjiangnan Road, Foshan City, 528000 Guangdong Province, P. R. China; e-mail: zlguo@ fosu.edu.cn

4) e-mail: wang8669@163.com

5) e-mail: zjp8866@163.com

(C) Koninklijke Brill NV, Leiden, 2005

Also available online: www.brill.nl

Crustaceana 78 (7): 839-850
} 
to genus rank, and listed six species of interest to fisheries in the Indo-West Pacific region. Chace \& Bruce (1993) stressed that the characteristically crested rostrum seems sufficient to justify full generic status for six or seven species originally assigned by Holthuis (1950) to the subgenus Exopalaemon. Liu (1955) treated three of its species among the economically important shrimps and prawns of northern China, viz., Palaemon (Exopalaemon) carinicauda (Holthuis, 1950), P. (E.) annandalei (Kemp, 1917), and P. (E.) modestus (Heller, 1862). Liu et al. (1990), in their overview of the Palaemoninae of China, recognized four species, viz., Exopalaemon modestus (Heller, 1862), E. carinicauda (Holthuis, 1950), E. orientis (Holthuis, 1950), and E. annandalei (Kemp, 1917). Liang (2000) subsequently described two new species, Exopalaemon xinjiangensis from Xinjiang Uygur Autonomous Region, northwestern China, and E. hainanensis from Hainan Province, southern China. Recently, a further faunistic and ecological survey of prawns was carried out in Guangdong Province, as a result of which an undescribed species, Exopalaemon guangdongensis new species, and a new record, E. modestus (Heller, 1862), are reported herein.

The following abbreviations are used in the text: tl, total body length (measured from the tip of the rostrum to the posterior margin of the telson); cl, carapace length (measured from the postorbital margin to the posterior margin of the carapace); rl, rostral length (measured from the tip of the rostrum to the postorbital margin); $\mathrm{m}$, merus length; c, carpus length; $p$, propodus length; f, finger; d, dactylus length; $i$, ischium length; chl, chela length. The notation for the rostral formula follows that of Chace \& Bruce (1993).

The primary type specimens are deposited in the collections of the Foshan Science and Technology College (FSTC). Some representative paratypes are deposited in Shanghai Fisheries University (SFU).

\section{SYSTEMATIC ACCOUNT}

Family PALAEMONIDAE Rafinesque, 1815

Genus Exopalaemon Holthuis, 1950

Exopalaemon guangdongensis new species (figs. 1-2)

Material examined. - Holotype ㅇ (FSTC, 03-06-18-01): tl $75.3 \mathrm{~mm}$, cl $14.9 \mathrm{~mm}$, rl $23.2 \mathrm{~mm}$; Zhujiang river, near Tangjiawan, Zhuhai City (c. $\left.22^{\circ} 36^{\prime} \mathrm{N} 113^{\circ} 36^{\prime} \mathrm{E}\right) ; 28$ June 2003; coll. Z. L. Guo.

Paratypes. - One o' (FSTC, 03-06-18-02): tl $80.5 \mathrm{~mm}$, cl $15.5 \mathrm{~mm}$, rl $21.0 \mathrm{~mm}$; 4 우 (FSTC, 03-06-18-03 to 06): tl 75.8-83.6 mm, cl 14.3-17.0 mm, rl 21.0-26.1 mm, collection data as holotype; 5 우 (FSTC, 04-04-16-07 to 11): tl 74.0-89.3 mm, cl 15.1-18.5 mm, rl 22.5-28.1 mm, Jiaomen river, near Panyu, Guangzhou City (c. $22^{\circ} 49^{\prime} \mathrm{N} 113^{\circ} 14^{\prime} \mathrm{E}$ ), 16 April 2004; coll. Z. L. Guo.

Description. - Rostrum (fig. 1A) very long, extending beyond the scaphocerite by about 2/5-1/2 of its length, about 1.2-1.7 times cl, elevated basal crest about 1/3 


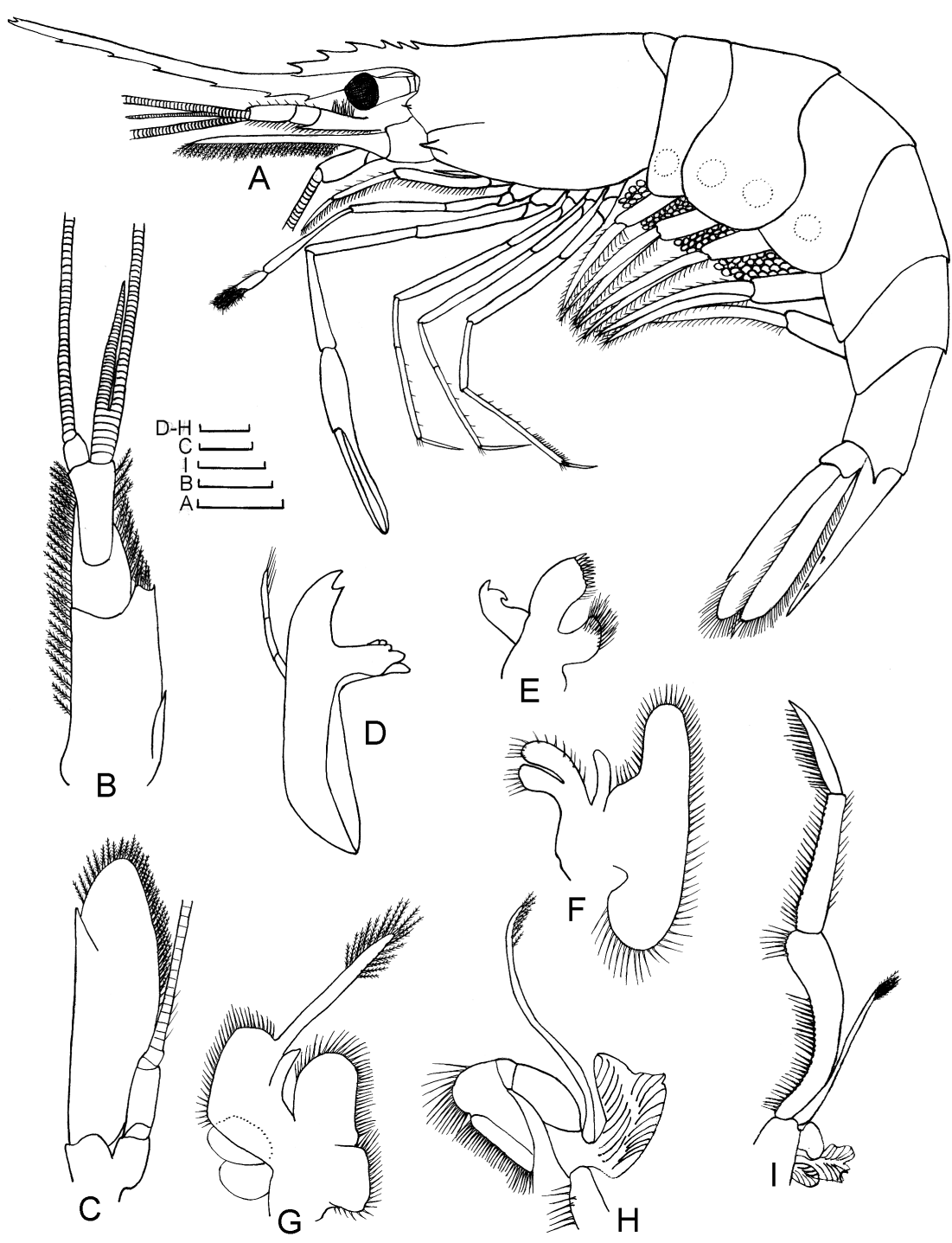

Fig. 1. Exopalaemon guangdongensis new species. A, entire animal, lateral view, holotype, ovigerous female, cl $14.9 \mathrm{~mm}$ (FSTC, 03-06-18-01). B-I, paratype, ovigerous female, cl $16.0 \mathrm{~mm}$ (FSTC, 0306-18-03). B, antennular peduncle; C, scaphocerite; D, mandible; E, maxillula; F, maxilla; G, first maxilliped; H, second maxilliped; I, third maxilliped. Scale bars indicate $1 \mathrm{~mm}(\mathrm{D}-\mathrm{H}), 2 \mathrm{~mm}(\mathrm{~B}, \mathrm{C}$, I), or $5 \mathrm{~mm}(\mathrm{~A})$.

of rl; distal part strongly upcurved; provided with 6-7 teeth on basal crest, of which 1 tooth placed behind the orbit, 1 dorsal terminal tooth, and 6-9 ventral teeth.

Carapace (fig. 1A) glabrous, entirely smooth; antennal spine much smaller than branchiostegal spine; with branchiostegal suture. 


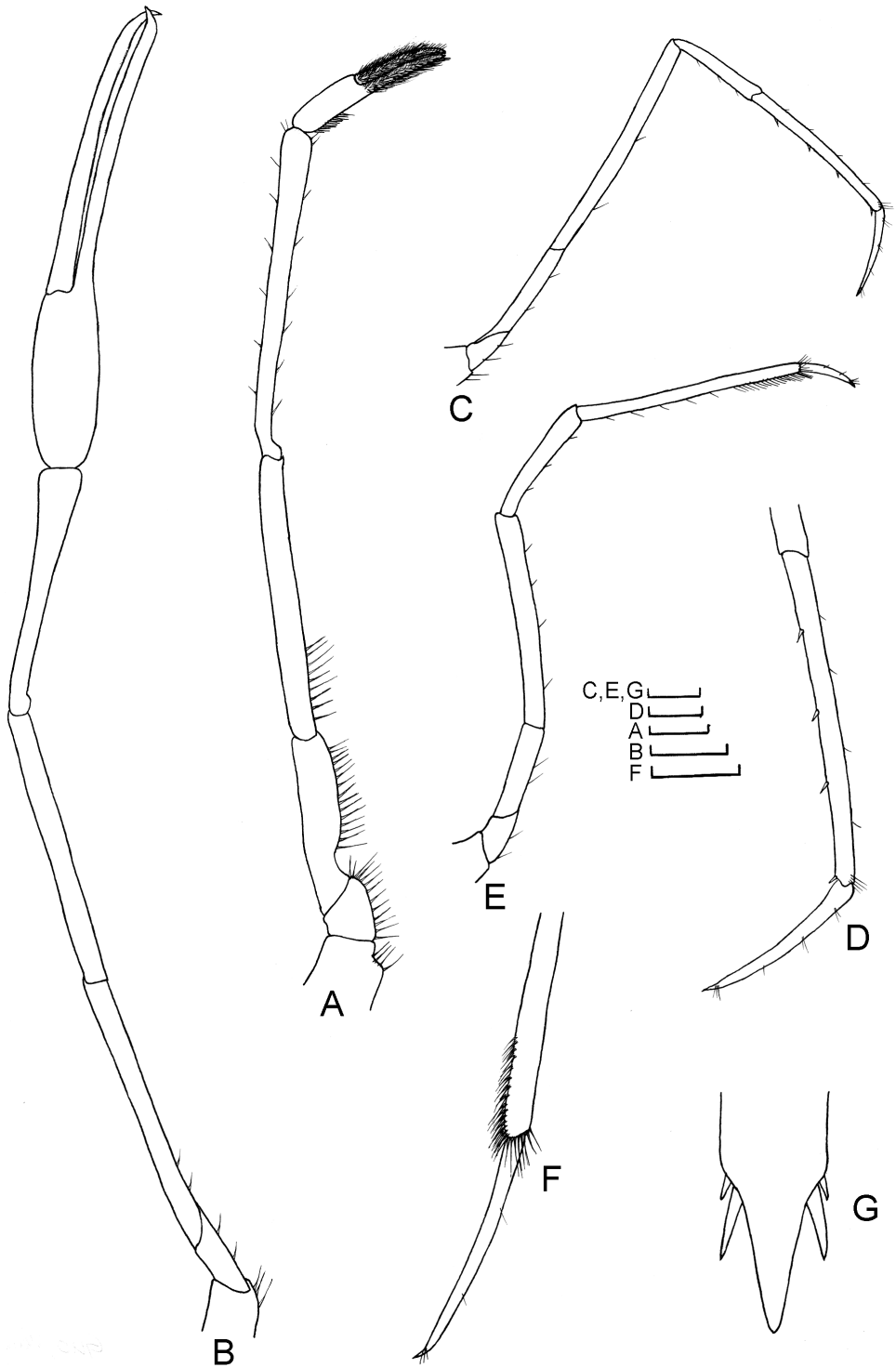

Fig. 2. Exopalaemon guangdongensis new species, paratype, ovigerous female, cl $16.0 \mathrm{~mm}$ (FSTC, 03-06-18-03). A, first pereiopod; B, second pereiopod; C, third pereiopod; D, dactylus of third pereiopod; E, fifth pereiopod; F, dactylus of fifth pereiopod; G, posterior portion of telson. Scale bars indicate $2 \mathrm{~mm}(\mathrm{~B}, \mathrm{C}, \mathrm{E}, \mathrm{G}, \mathrm{H})$ or $1 \mathrm{~mm}(\mathrm{~A}, \mathrm{D}, \mathrm{F})$.

Antennule (fig. 1A, B) with stylocerite sharp, reaching about middle of basal segment of antennular peduncle, anterior margin of basal segment distinctly convex, with small acute tooth, second segment as long as third; shorter branch 
of outer flagellum about $1 / 2$ of cl, fused part with 7 segments, free part with $30-32$ segments.

Antenna (fig. 1A, C) with scaphocerite large, 2.3-3.2 times as long as wide, outer margin ending in a strong spine, which is overreached by the broad lamella.

Mandible (fig. 1D) palp three-segmented; incisor process robust, ending in two sharp teeth; molar process stout, distally excavated, with blunt teeth and ridges.

Maxillula (fig. 1E) palp bilobed; upper lacinia broadly elongated, distal margin straight, with row of strong spines, lower lacinia slender, broad, densely setose distally.

Maxilla (fig. 1F) palp tapering; basipodal endite proximally broad, deeply bilobed, upper lobe with numerous simple setae distally, sparse, simple setae along lateral margin, lower lobe with numerous simple setae distally; scaphognathite broad, about 3.0 times as long as wide.

First maxilliped (fig. 1G) with subcylindrical, distally tapering palp, basipodal and coxal endites distinct; exopod with large caridean lobe, flagellum with numerous plumose setae distally, epipod deeply bilobed, oval.

Second maxilliped (fig. 1H) with endopod normal, with fused dactylar and propodal segments; exopod well developed, flagellum with plumose setae distally, epipod simple, with well-developed podobranch.

Third maxilliped (fig. 1I) with endopod robust, ischiomerus bow-shaped, slightly expanded distally, with row of long, simple setae on inner margin; carpus about 0.71 times length of ischiomerus, with row of long, simple setae on inner margin and sparse row of simple setae on outer margin; distal segment about 0.77 times penultimate segment, ending in a strong, claw-like spine, with row of long, simple setae on inner margin; exopod reaching to about $2 / 3$ of ischiomerus, bearing long, plumose setae distally, with well developed oval lateral plate, large mutilamellar arthrobranch, and small pleurobranch.

Branchial formula as in table I.

TABLE I

Branchial formula of Exopalaemon guangdongensis new species

\begin{tabular}{lccccccccc}
\hline & \multicolumn{3}{c}{ Maxillipeds } & & \multicolumn{5}{c}{ Pereiopods } \\
\cline { 2 - 4 } \cline { 6 - 8 } & 1 & 2 & 3 & & 1 & 2 & 3 & 4 & 5 \\
\hline Pleurobranchs & - & - & 1 & & 1 & 1 & 1 & 1 & 1 \\
Arthrobranchs & - & - & 1 & & - & - & - & - & - \\
Podobranchs & - & 1 & - & & - & - & - & - & - \\
Epipods & 1 & 1 & 1 & & - & - & - & - & - \\
Exopods & 1 & 1 & 1 & & - & - & - & - & - \\
\hline
\end{tabular}


First pereiopod (fig. 2A) slender, reaching beyond scaphocerite; fingers longer than palm, with dense, simple setae; carpus 1.8-1.9 times as long as chela; merus 0.83-0.94 times as long as carpus, and 1.3-1.8 times as long as ischium.

Second pereiopod (fig. 2B) shorter than body, reaching beyond scaphocerite by 1/2 palm length; finger about 1.4-1.7 times as long as palm, cutting edge entire, unarmed, hooked tips distally, gaping when closed, sparsely setose; carpus about 1.2-1.4 times as long as palm; merus about 1.1-1.2 times as long as carpus, and about as long as ischium.

Third pereiopod (fig. 2C, D) slender, reaching to distal end of antennular peduncle; propodus 1.4-1.9 times as long as dactylus; carpus about 1.1 times as long as dactylus; merus about 1.4-1.9 times as long as propodus, and about 1.6-2.0 times as long as ischium.

Fifth pereiopod (fig. 2E, F) longer and larger than third or fourth pereiopod, reaching beyond scaphocerite; propodus 2.8-4.1 times as long as dactylus, with 15-20 oblique rows of serrulate setae on posterior margin, and about 1.7-2.1 times as long as carpus; merus about 2.1-2.2 times as long as ischium.

The endopod of the first pleopod in the male is oval-shaped, without appendix interna. The second pleopods in the male are provided with an appendix interna as well as with an appendix masculina.

Abdomen (fig. 1A) glabrous, smooth; pleura of the first six somites broadly rounded; sixth somite about 0.48-0.55 times cl, and about 1.4-1.7 times as long as fifth somite; the last four abdominal somites are sharply carinate dorsally.

Telson (figs. 1A, 2G) smooth, about 1.3-1.5 times as long as sixth abdominal somite; dorsal surface with two pairs of spines; posterior margin tapering regularly to a sharp point and bearing two pairs of posterior spines, the outer pair shorter than the inner.

Live coloration. - When alive, the body is whitish opaque and with numerous small, reddish dots; posterior endopod of uropod reddish. There are four large, blue-black spots on the pleurae in ovigerous females, one on the first, two on the second, and one on the third pleuron. The eggs are greenish yellow.

Egg size. - Small; the eggs measure 0.40-0.46 × 0.51-0.60 mm.

Etymology. - The species is named after the type locality, Guangdong Province, southern China. The species name thus is an adjective agreeing in gender with the (masculine) generic name.

Remarks. - Exopalaemon guangdongensis new species is most similar to $E$. styliferus (H. Milne Edwards, 1840), but it can easily be distinguished from $E$. styliferus by its rostral formula, which has only one terminal tooth (versus 1-3 subterminal teeth); the 4 posterior abdominal somites sharply carinate in dorsal mid-line (versus not sharply carinate); the merus of the second pereiopod as long as 
the ischium (versus shorter than ischium); and the finger distinctly longer than the ischium (versus shorter than ischium); the shorter dactlyus on the fifth pereiopods (dactlyus about $1 / 4$ or less of propodus versus dactlyus about $1 / 3$ of propodus in $E$. styliferus); and the smaller eggs (eggs size $0.40-0.46 \times 0.51-0.60 \mathrm{~mm}$ versus 0.56 $0.61 \times 0.65-0.82 \mathrm{~mm})$. Exopalaemon guangdongensis morphologically resembles E. carinicauda (Holthuis, 1950) in having a sharp carina in the dorsal mid-line of the third to sixth abdominal somites. It can be distinguished from E. carinicauda by the rostral formula, which has more ventral teeth (6-9 versus 3-6); the shorter palm on the second pereiopod (carpus about 1.2-1.4 times as long as palm versus carpus about as long as palm), merus about as long as ischium (versus merus shorter than ischium); the shorter dactlyus of the fifth pereiopods (dactlyus about $1 / 4$ or less of propodus versus dactlyus about $1 / 2$ of propodus); and also the smaller eggs (eggs size $0.40-0.46 \times 0.51-0.60 \mathrm{~mm}$ versus $0.50-0.70 \times 0.70-0.90 \mathrm{~mm})$. The differences between these species are presented in table II.

Habitat. - The type specimens were collected from the Zhujiang River, near Tangjiawan, Zhuhai City, Guangdong Province (c. $22^{\circ} 36^{\prime} \mathrm{N} 113^{\circ} 36^{\prime} \mathrm{E}$ ), and the

TABLE II

Comparison between E. guangdongensis, E. carinicauda, and E. styliferus

\begin{tabular}{lccc}
\hline & $\begin{array}{c}\text { E. guangdongensis sp. } \\
\text { nov. }\end{array}$ & $\begin{array}{c}\text { E. carinicauda } \\
\text { Holthuis }\end{array}$ & $\begin{array}{c}\text { E. styliferus } \\
\text { H. Milne Edwards }\end{array}$ \\
\hline $\begin{array}{l}\text { Rostral formula } \\
\text { First pereiopod }\end{array}$ & $1+5-6+1 / 6-9$ & $1+5-8+1 / 3-6$ & $1+4-6+1-3 / 6-10$ \\
Ratio of chl/i & $<1$ & $>1$ & $>1$ \\
Ratio of c/m & $>1$ & $>1$ & $<1$ \\
Second pereiopod & $>1$ & $=1$ & $>1$ \\
Ratio of c/p & $>1$ & $>1$ & $<1$ \\
Ratio of f/i & $=1$ & $<1$ & $<1$ \\
Ratio of m/i & & $>1$ & $<1$ \\
Third pereiopod & $<1$ & $>1$ & $>1$ \\
Ratio of d/c & $<1$ & $<1$ & $=1 / 2$ \\
Ratio of d/i & $<1$ & $>3 / 4$ & $<1$ \\
Ratio of c/i & $>1 / 2$ & $>1$ & $=1 / 3$ \\
Ratio of d/p & $<1 / 2$ & $=1 / 2$ & $<1$ \\
Fifth pereiopod & $=1 / 4$ & $>1$ & Blunt \\
Ratio of d/c & $<1$ & Sharp & \\
Ratio of d/p & Sharp & & \\
Ratio of d/i & & & $0.56-0.61 \times 0.65-0.82$ \\
Dorsal mid-line & & &
\end{tabular}


Jiaomen River, near Panyu, Guangzhou City, Guangdong Province (c. $22^{\circ} 49^{\prime} \mathrm{N}$ $\left.113^{\circ} 14^{\prime} \mathrm{E}\right)$. The conditions were estuarine; $\mathrm{pH}$ was 7.0-7.5.

Distribution in China. - Guangdong Province.

\section{Exopalaemon carinicauda (Holthuis, 1950)}

Leander longirostris carinatus Ortmann,1890: 521 [type locality: China].

Leander carinatus, Doflein, 1902: 639.

Leander styliferus carinatus Balss, 1914: 57.

Palaemon carinatus, Sowerby, 1925: 133.

Palaemon (Exopalaemon) carinicauda Holthuis, 1950: 9, 48. — Liu, 1955: 48.

Exopalaemon carinicauda, Holthuis, 1980: 83. — Liu et al., 1990: 245.

Material examined. - Three 우, $1 \sigma^{\top}$ (FSTC, 03-06-28-01), cl 11.0-15.5 mm, Zhujiang River near Tangjiawan, Zhuhai City, 28 June 2003; coll. Z. L. Guo. Four 14.0-17.5 mm, Zhanjiang City, 4 July 2002; coll. Z. L. Guo. Six 우, $10^{7}$ (FSTC, 03-08-10-01), cl 12.5-17.9 mm, Zhaopo Town, Yangjiang City, 10 August 2003; coll. Z. L. Guo.

Remarks. - This species is easily recognized among the white prawns in China, and is distinguished by its unusually sharp carination in the dorsal mid-line of the third-sixth abdominal somites. It is very similar to Exopalaemon guangdongensis in shape and size. The distinctions between the two taxa are discussed above, under that species. The carpus is equal to the palm in the second pereiopod, and this is the most important diagnostic character for the present species.

This is by far the most widespread white prawn in coastal China. It is common and commercially important, in the Bohai Sea and the Huanghai Sea (Li et al., 2003). In recent years, it has been cultivated in Zhejiang (Chen et al., 2000) and Jiangsu Province (Sun, 2002), eastern China.

Distribution in China. - Coastal China (Liaoning, Hebei, Shandong, Jiangsu, Zhejiang, Fujian, Guangdong, Guangxi, Hainan, and Hongkong).

General distribution. - From Korea to Singapore.

\section{Exopalaemon orientis (Holthuis, 1950)}

Leander longirostris japonicus Ortmann, 1890: 519 [type locality: Tokyo, Japan].

Palaemon japonicus, Rathbun, 1902: 50.

Palaemon (Exopalaemon) orientis Holthuis, 1950: 9, 49.

Exopalaemon orientis, Holthuis, 1980: 83. — Liu et al., 1990: 246. — Li et al., 2004: 515.

Material examined. - Two ㅇ, 2 o $^{\top 7}$ (FSTC, 03-06-28-02), cl 10.2-12.3 mm, Zhujiang River, near Tangjiawan, Zhuhai City, 28 June 2003; coll. Z. L. Guo. One $q$ (FSTC, 03-08-10-02), cl 17.0 mm, Zhaopo Town, Yangjiang City, 10 August 2003; coll. Z. L. Guo.

Remarks. - Exopalaemon orientis appears closely similar to E. carinicauda, but it can easily be distinguished from the latter by the absence of carinae in the 
dorsal mid-line of the third to sixth abdominal somites. The present specimens agree with the descriptions of Liu et al. (1990). This species is distributed naturally throughout southeastern coastal China (Liu et al., 1990; Li et al., 2003).

Distribution in China. - Southeastern coastal China (Fujian, Taiwan, Guangdong, and Hainan).

General distribution. - From Japan to Korea, and southeastern China.

Exopalaemon modestus (Heller, 1862)

Leander modestus Heller, 1862: 527 [type locality: Shanghai, China].

Leander modestus sibirica Brashnikov, 1907: 176 [type locality: Tungush River, Amur basin, Russia].

Leander czerniavskyi Brashnikov, 1907: 176 [type locality: mouth of the Amur River, Russia].

Palaemon modestus, Sowerby, 1925: 133.

Palaemon (Exopalaemon) modestus Holthuis, 1950: 9, 51. — Liu, 1955: 50. — Zhang \& Sun, 1981: 3 .

Exopalaemon modestus, Holthuis, 1980: 83. — Liu et. al., 1990: 246.

Material examined. - Five 우, $2 \circ^{7} \sigma^{7}$ (FSTC, 02-07-01), cl 7.5-13.5 mm, Beijiang River, near Shaoguan City, 1 July 2002; coll. Z. L. Guo. Five 우, 5 o $^{7} \sigma^{7}$ (FSTC, 02-07-03), cl 7.2-12.8 mm, Zhenjiang River, near Shixing County, 3 July 2002; coll. Z. L. Guo.

Remarks. - This is a common and commercially important white prawn in China. The species is distributed in the middle and lower reaches of the Yangtze River, in northern and northeastern China. This is the first record of this species from Guangdong Province. It is restricted to fresh waters, has been found in rivers, lakes, and reservoirs. It is usually found together with Marcobrachium nipponense (De Haan, 1849). In some large lakes, the fishery production of this species is about $1 / 2$ or more of the total landings of prawns. It is made into a dried product and sold as food at markets all over China. Because of its excellent flavour, in recent years, it has been cultivated at a considerable scale in Yunan (Li et al., 2003) and also in Zhejiang Province (Hu et al., 2002).

Distribution in China. - The middle and lower reaches of Yangtze River, northern and northeastern China.

General distribution. - Russia and China.

\section{DISCUSSION}

White prawns of the genus Exopalaemon are an important component of the freshwater, estuarine, and marine ecosystems throughout the tropical, subtropical, and warm temperate areas of the Indo-West Pacific. The Chinese fauna now comprises seven species. Two species are restricted to fresh waters: E. modestus, distributed naturally in the middle and lower reaches of Yangtze River, northern, 
and northeastern China, extends its distributional range northward to Siberia. E. xinjiangensis is only known from the type locality (Talimu River, Xijiang, northwestern China). E. annandalei prefers fresh waters, the lower reaches of rivers, but sometimes also occurs in estuaries; it is distributed naturally in eastern and northern China, and in Korea. Four species, E. orientis, E. carinicauda, E. hainanensis, and E. guangdongensis are distributed in brackish and marine waters. E. orientis occurs in southeast coastal China, southern coastal Korea, and Japan. E. carinicauda is the most widespread species in coastal China. It is also common in western coastal Korea. E. guangdongensis is only known from the type locality (Zhujiang estuary, southern China).

White prawns are a precious aquatic resource of China. Many species grow to sufficient size to be used for human consumption. In recent years, because of the size and the excellent flavour of white prawns, E. carinicauda and $E$. modestus have been cultivated at a considerable scale in the Zhejiang, Jiangsu, and Yunan Provinces; E. xinjiangensis has been cultivated in Yili, Xinjiang Uygur Autonomous Region.

\section{KEY TO THE SPECIES OF THE GENUS EXOPALAEMON IN CHINA}

1. Rostrum long, distinctly longer than carapace, elevated basal crest shorter than the slender distal

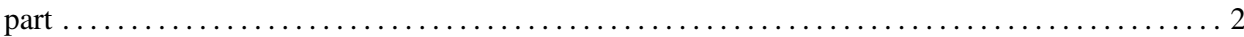
- Rostrum short, as long as or shorter than carapace, elevated basal crest longer than the slender

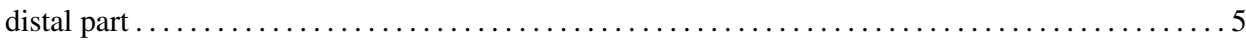

2. Four posterior abdominal somites sharply carinate in dorsal mid-line $\ldots \ldots \ldots \ldots \ldots \ldots \ldots . \ldots \ldots$

- Four posterior abdominal somites not sharply carinate in dorsal mid-line . . . . . . . . . . . . . 4

3. Carpus of second pereiopod longer than palm, merus as long as ischium $\ldots \ldots \ldots \ldots \ldots \ldots \ldots$.

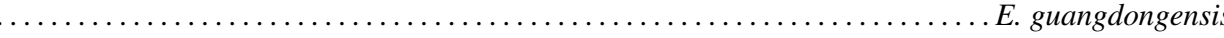

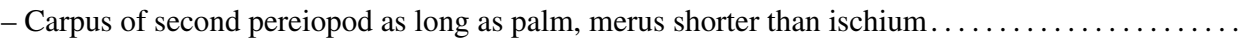

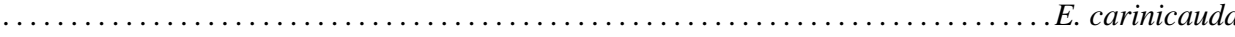
4. Carpus of second pereiopod shorter than palm, dactylus of fifth pereiopod as long as propodus ..

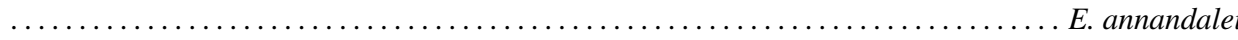
- Carpus of second pereiopod longer than palm, dactylus of fifth pereiopod shorter than propodus .

5. Carpus of second pereiopod as long as or slightly longer than chela $\ldots \ldots \ldots \ldots \ldots \ldots \ldots \ldots$

- Carpus of second pereiopod distinctly shorter than chela .................. hainanensis 6. Rostrum dentate throughout its length or unarmed on anterior $1 / 3$ of dorsal margin, eggs

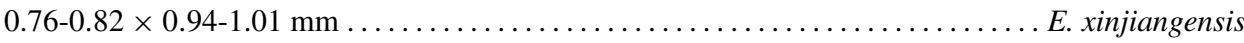
- Rostrum unarmed on anterior $1 / 2$ of dorsal margin, eggs $0.96-1.01 \times 1.20-1.32 \mathrm{~mm} \ldots \ldots \ldots \ldots$.

E. modestus

\section{ACKNOWLEDGEMENTS}

We wish to express our sincere gratitude to Dr. L. B. Holthuis, National Museum of Natural History, Leiden, The Netherlands, for reading and correcting 
the manuscript and for his suggestions and comments, and also to Prof. X. Q. Liang (SFU) and Dr. S. De Grave of the Oxford University Museum of Natural History for critically reading the manuscript. We thank Dr. L. B. Holthuis, Dr. S. De Grave, Dr. Y. X. Cai, Dr. S. C. Choy, Dr. H. Suzuki, Dr. K. I. Hayashi, and Dr. S. Li for providing us with essential literature.

\section{REFERENCES}

BALsS, H., 1914. Ostasiatische Decapoden, II: Die Natantia und Reptantia. In: F. Doflein (ed.), Beiträge zur Naturgeschichte Ostasiens. Abhandlungen der Bayerischen Akademie der Wissenschaften zu München, (Mathematish-Physikalischen Klasse) (supplement) 2 (10): 1-101, figs. 1-50, pl. 1.

BRASHNiKov, V., 1907. Material representing the fauna of the eastern Russian seas collected by the schooner "Storosh" in 1899-1902. Memoirs of the Imperial Academy of Sciences of St. Petersburg, (8) 20 (6): 1-185, figs. 1-26, pls. 1-2.

Chace, F. A., JR. \& A. J. Bruce, 1993. The caridean shrimps (Crustacea: Decapoda) of the Albatross Philippine expedition 1907-1910, Part 6: superfamily Palaemonoidea. Smithsonian Contributions to Zoology, 543: 1-152, figs. 1-23.

Chen, X. L., H. N. Rong \& B. D. Lin, 2000. Pond rearing test on Exopalaemon carinicauda. Fisheries Science, 19 (6): 22-23.

Doflein, F., 1902. Ostasiatische Decapoden. Abhandlungen der Bayerischen Akademie der Wissenschaften, München, 21: 613-670, figs. A-D, pls. 1-6.

Heller, C., 1862. Neue Crustaceen gesammelt während der Weltumseglung der k. k. Fregatte Novara: zweiter vorläufiger Bericht. Verhandlungen des Kaiserlich-königlichen Zoologischbotanischen Gesellschaft in Wien, 12: 519-528.

Holthuis, L. B., 1950. The Decapoda of the Siboga Expedition, Part X: the Palaemonidae collected by the Siboga and Snellius expeditions with remarks on other species, Part I: subfamily Palaemoninae. Siboga Expeditie Mon., Leiden, 39a (9): 1-268, figs. 1-52.

— - 1980. Shrimps and prawns of the world: an annotated catalogue of species of interest to fisheries. FAO Fisheries Synopsis, 125 (1): 1-261.

HU, T. J., T. Y. Ye, Z. M. ZhANG, X. K. Wei \& Z. K. XU, 2002. Pond rearing on Exopalaemon modestus. Scientific Fish Farming, 2: 31.

KEMP, S., 1917. Notes on crustacean Decapoda in the Indian Museum, IX: Leander styliferus MilneEdwards, and related forms. Records of the Indian Museum, 13 (4): 203-231, figs. 1-2, pls. 8-10.

Li, X. Z., A. J. BRuce \& R. B. MAnning, 2004. Some palaemonid shrimps (Crustacea: Decapoda) from northern South China Sea, with descriptions of two species. The Raffles Bulletin of Zoology, 52 (2): 513-553.

LI, X. Z., R. Y. LIU \& X. Q. LiAnG, 2003. The zoogeography of Chinese Palaemonoidea fauna. Biodiversity Science, 11 (5): 393-406.

LIANG, X. Q., 2000. On two new species of Exopalaemon from China (Decapoda: Palaemonidae) Acta Zootaxonomica Sinica, 25 (3): 277-281, figs. 1-19.

LIU, J. Y., 1955. Economic shrimps of northern China: 1-73, pls. 1-24. (Science Press, Beijing).

LiU, R. Y., X. Q. LiAng \& S. L. YAN, 1990. A study of the Palaemoninae (Crustacea Decapoda) from China II. Palaemon, Exopalaemon, Palaemonetes and Leptocarpus. Studia Marina Sinica, 31: 229-265, figs. 23-42, pl. 1.

Milne Edwards, H., 1840. Histoire naturelle des Crustacés, comprenant l'anatomie, la physiologie et la classification de ces animaux, 3: i-ii, 1-638. (Paris). 
Ortmann, A., 1890. Die Unterordnung Natania Boas: die Decapoden-Krebse des Strassburger Museums, mit besonderer Berücksichtigung der von Herrn Dr. Döderlein bei Japan und bei den Liu-Kiu-Inseln gesammelten und z. Z. im Strassburger Museum aufbewahrten Formen, I. Zoologische Jahrbücher, (Systematik, Geographie und Biologie der Thiere) 5: 437-542.

Rathbun, M. J., 1902. Japanese stalk-eyed crustaceans. Proceedings of the United States National Museum, 26: 23-55, figs. 1-24.

SOWERBY, A. DE C., 1925. A naturalist's note book in China: 1-270.

SUN, Y. K., 2002. Rearing Exopalaemon carinicauda in low salinity field benefit pond. Jangsu Province Salt Science \& Technolgy, 4: 12-13.

ZHANG, J. \& X. SUN, 1981. A preliminary investigation on the middle and lower reaches of the Yangtze River. Chinese Journal of Zoology, 4: 2-6, figs. 1, 2.

First received 11 March 2005

Final version accepted 24 May 2005. 